\title{
Erratum to: Full endoscopic endonasal expanded approach to the petroclival region: optimizing the carotid-clival window
}

\author{
Juan Antonio Simal-Julián • Pablo Miranda-Lloret • \\ Carlos Botella-Asunción • Amin Kassam
}

Published online: 10 June 2014

(C) Springer-Verlag Wien 2014

\section{Erratum to: Acta Neurochir}

DOI 10.1007/s00701-014-2125-6

The original version of this article unfortunately contained mistakes. The name of the fourth author "Amin Kassam" was written incorrectly and is now corrected in the author group of this article, as well, the affiliation and conflict of interest of Dr Amin Kassam are incorrect.

Affiliation: Amin Kassam MD, Aurora Neuroscience Innovation Institute, Aurora St. Luke's Medical Center, Milwaukee, WI, USA.

Conflict of interest: Dr Kassam is a Cofounder of Synaptive medical and Regenerative Cell Sciences. He is also chairs the scientific advisory board for NICO Cooperation. He holds equity stakes in NICO Co., Synaptive Medical, And Regenerative Cell Sciences, and he also received royalties from KLS Martin.

The online version of the original article can be found at http://dx.doi.org/ 10.1007/s00701-014-2125-6.

J. A. Simal-Julián $(\bowtie) \cdot$ P. Miranda-Lloret $\cdot$ C. Botella-Asunción Neurosurgical Department, HUiP La Fe de Valencia, Blv Sur,

Valencia, S/N 46026, Spain

e-mail: juanantonio.simal@gmail.com

\section{A. Kassam}

Aurora Neuroscience Innovation Institute, Aurora St. Luke's Medical

Center, Milwaukee, WI, USA 